Engelbrecht $L K$

\title{
OPERATIONALISING A COMPETENCE MODEL OF SUPERVISION TO EMPOWER SOCIAL WORKERS AND STUDENTS IN SOUTH AFRICA
}

\author{
Dr LK Engelbrecht is a Senior Lecturer in the Department of Social Work, University of \\ Stellenbosch
}

\section{ABSTRACT}

The purpose of this article is to demonstrate, with reference to the work of Guttman, Eisikovits \& Maluccio (1988), how a competence model of supervision for social workers and students in South Africa can be operationalised. This will be done by showing the relevance of a competence model for supervision in South Africa and by explaining, with reference to outcomes-based and empowerment supervision, the rationale behind the operationalisation of the competence model. The competence model will then be conceptualised so as to provide a theoretical foundation for the model. The operationalisation of the competence model is demonstrated by defining outcomes-based supervision, explaining the relevant principles of outcomes-based supervision, defining empowerment supervision, indicating the differences between traditional and empowerment supervision, and by clarifying the relevant principles of empowerment.

\section{INTRODUCTION}

In their article "Enriching social work supervision from the competence perspective" the authors Guttman, Eisikovits \& Maluccio (1988:278-290) state that the manifest goal of supervision in social work generally has become associated with the promotion of competence. However, these authors also say that interpretations of the concept vary and that explicitly stated competenceoriented models of supervision are rare. According to the authors, there is an obvious lack of clear and explicitly formulated competence-oriented supervision models.

The purpose of this article is to demonstrate, with reference to the work of Guttman et al. (1988), how a competence model of supervision for social workers and students in South Africa can be operationalised. This will be done by showing the relevance of a competence model for supervision in South Africa and by explaining, with reference to outcomes-based and empowerment supervision, the rationale behind the operationalisation of the competence model. The competence model will then be conceptualised so as to provide a theoretical foundation for the model. The operationalisation of the competence model is demonstrated by defining outcomesbased supervision, explaining the relevant principles of outcomes-based supervision, defining empowerment supervision, indicating the differences between traditional and empowerment supervision, and by clarifying the relevant principles of empowerment.

\section{RELEVANCE OF THE COMPETENCE MODEL FOR SUPERVISION IN SOUTH AFRICA}

It would appear that a competence model as a model of supervision for social workers/students is eminently suited to the current South African situation, because the implementation of policy as stipulated by the White Paper for Social Welfare (Ministry for Welfare and Population Development, 1997) and the South African Qualifications Authority Act (RSA Ministry of Education, 1995) both require that social workers and students demonstrate specific competencies. 
The White Paper for Social Welfare (1997) calls for traditional social work practice to be reformed and for services to be rendered from a social developmental perspective. The White Paper proposes a welfare system that would facilitate the development of human capacity. Facilitating the development of human capacity means that certain principles, priorities, strategies and outcomes of social development have to be met, and that social workers need to be particularly competent in specific areas (Ministry for Welfare and Population Development, 1997).

The nature and scope of social work education in South Africa has been transformed by the South African Qualifications Authority (SAQA), in accordance with the requirements laid down by the South African Qualifications Authority Act (RSA Ministry of Education, 1995). The Regulations under the South African Qualifications Authority Act (SAQA, 1998) require that tertiary training institutions provide education that is in line with the new dispensation. Self-evaluation and comprehensive descriptions of programmes and outcomes take high priority at all training institutions in South Africa with a view to meeting the requirements of the National Qualifications Framework (NQF). The change in the education system in South Africa entailed a change from a content-based approach to an outcomes-based approach. Outcomes-based education does not focus only on that which is learned, but also on how it is learned. It is integrated in terms of competencies (SAQA, 1998).

\section{RATIONALE FOR THE OPERATIONALISATION OF THE COMPETENCE MODEL BY MEANS OF OUTCOMES-BASED AND EMPOWERMENT SUPERVISION}

The characteristics of the competence model are directly related to the nature of outcomes-based education, as both focus on outcomes, the demonstration thereof, specific assessment criteria, retrospective planning and facilitation (Engelbrecht, 2002:74). Offering outcomes-based supervision that is focused on the demonstration of competencies is therefore an operationalisation of the competence model.

More than a decade ago Ramasar (1988:186) highlighted the fact that in the indigenous South African environment more and more students from previously disadvantaged environments were studying social work. The author points out the implication of this by mentioning that, apart from the previous inequality in learning opportunities, factors such as ethnicity, culture and the local idiom also influence the nature of education. It is therefore necessary to adapt traditionally Western educational processes, methods and techniques in order to accommodate both the diversity and the needs of indigenous students. In addition, research by Engelbrecht (2002:215) reveals that $85 \%$ of the training institutions in South Africa have $80 \%$ to $100 \%$ of social work students who come from previously disadvantaged communities. The author argues that these students can be regarded as disempowered, because they often do not possess adequate life skills nor do they meet the social requirements of a professional practice environment. These students need to be empowered to demonstrate effective and efficient competencies, as social workers, which will allow them to adapt to different and changing practice environments and practice situations (Engelbrecht, 2002:249-250).

It seems therefore that a changed welfare and education policy, a changed work and learning environment and a change in the cultural composition of the student body in social work education make it essential to apply a situation-relevant supervision model focused on developing the competencies of workers/students. These factors add to the necessity for outcomes-based and empowerment supervision to be an inextricable part of the operationalisation of a competence model in South Africa. It is in this context that Engelbrecht (2002:256-257) recommends, among other things, that supervision in South Africa be interpreted as empowerment from a strength 
perspective, that supervision be outcomes-based, and that supervision take place according to a situation-relevant but theoretically accountable competence model.

\section{CONCEPTUALISATION OF THE COMPETENCE MODEL}

A model can be defined as a structured and adaptable exposition of reality (Kaplan, 1991:11; Shardlow \& Doel, 1996:31-33). According to authors such as Tsui and Ho (1997:186), a model of supervision for social workers/students is imperative, because it is difficult to gain a holistic understanding of supervision without the use of models. However, explicit competence-oriented models of supervision are rare (Guttman et al., 1988:280).

A competent social worker/student is someone who does the right thing at the right time and in the right place. In its simplest form competency is a person's capacity to interact effectively with the environment (Guttman et al., 1988). Competency therefore refers to the knowledge, values and skills that a worker/student uses to bring about change or to encourage development in the environment, the people in the environment and the people's needs by means of intervention.

Shardlow and Doel's (1996:41-43) conceptualisation of the competence model shows why this model can be regarded as an appropriate model of supervision for social workers/students. According to these authors, the model focuses on the outcomes of supervision rather than on the process followed to achieve these outcomes. Workers/students must be able to demonstrate that they have attained set outcomes, so as to prove that they have successfully accomplished certain tasks. Specific assessment criteria are used to indicate different levels of competency. The competence model also focuses on the final results that are expected. It is therefore the starting point of supervision. The supervisor plays a facilitating role which enables workers/students, through supervision, to achieve the anticipated outcomes and demonstrate specific competencies.

Guttman et al. (1988) identify certain content categories according to which competencies are differentiated. These authors distinguish between intellectual competence, performance competence, personal competence and consequence competence. These are discussed below.

Intellectual competence involves knowing what to do, when to do it and with whom to do it. The focus is on practical and useful knowledge, but also on the development of more abstract knowledge. Being competent in knowing what knowledge to apply to particular people and circumstances is therefore the competence that is being developed. This competence must be specifically identified and the worker/student must practise it and be able to demonstrate it. During supervision competencies must be carried over from one situation to another and must be adapted according to the demands of the environment and the situation. The transfer of competencies from one situation to another is a pivotal aspect of the competence model.

Performance competence involves knowing how to act in any given situation. In this regard the focus during supervision is on the ecological perspective. The worker/student must therefore be able to assess the impact of systems in the environment. Strengths in the environment must be facilitated, while limitations must be inhibited. Through this, workers/students must also be enabled to critically evaluate their performance.

Personal competence consists of the worker/student's understanding of him/herself and the need for self-development. It develops from the reciprocal relationship between the worker/student and the supervisor. This relationship lays the foundation for the various roles that the supervisor and the worker/student play during supervision. The supervisor's role is to promote workers'/students' self-awareness and to assist them in understanding their work and related situations, so that they can apply their knowledge to these situations. The supervisor's role is also to highlight for the 
benefit of the workers/students those areas where self-development is necessary and to propose ways in which their self-development can be promoted. The supervisor must therefore provide the worker/student with opportunities for professional development. The worker's/student's role is to be actively involved in his/her own development. Specific outcomes for personal competence and appropriate assessment criteria must be developed together.

Consequence competence involves facilitating the workers'/students' efforts to determine the effectiveness of their intervention. This takes place on two levels. The first level focuses on an ecological assessment, which workers/students do to determine the extent to which their interventions have influenced the interaction between systems and whether development has taken place on the part of the consumer system. The second level focuses on the extent to which the goals of intervention, aided by the intervention plan, have been achieved. This implies that a baseline assessment is done prior to intervention, which is then measured again during and after intervention.

\section{OUTCOMES-BASED SUPERVISION}

The above-mentioned conceptualisation of the competence model has direct relevance to outcomes-based supervision, since both focus on outcomes and their demonstration, assessment criteria, retrospective planning and facilitation. Outcomes-based supervision is therefore an inextricable part of the competence model of supervision.

\section{Definition of outcomes-based supervision}

Outcomes-based supervision involves a paradigm shift away from the inputs of the supervisor towards a focus on the outcomes of supervision. The focus of supervision shifts from what is offered in supervision and how it is presented, to what and how workers/students develop. Outcomes-based supervision, as with outcomes-based education on primary, secondary and tertiary level, is worker/student centred. This entails deciding beforehand what workers/students must know, what they must be able to do, and what they must feel and believe about it all (Luckett, 1997; Pretorius, 1998:ix; SAQA, 1998).

In order to understand outcomes-based supervision, it is necessary to define the term "outcomes". SAQA (1998) defines outcomes as "...the contextually demonstrated end-products of the learning process." Outcomes may be interpreted as a culminating demonstration of a whole series of learning experiences and competencies. An outcome is therefore not only the name given to the learning content, the name of a concept, competence, degree or test mark, but a real demonstration of achievement in a reliable context (Luckett, 1997). This is why an outcome must be observable and why it must be possible to evaluate it, why it must contain procedures that can be followed, be supported by underlying knowledge, values and skills, why it must result in certain competencies, and why clearly formulated assessment criteria must be specified. An outcome contains a verb to denote action, an object or noun and, if necessary, a word or parameter with which to qualify it (Luckett 1997; Olivier 1998:24-28).

\section{Principles of outcomes-based supervision}

In the following section the principles of outcomes-based education, as explicated in the publications of Claassen (1998), Pretorius (1998) and SAQA (1998), will be discussed. These principles will be applied to the supervision of social workers/social work students.

The success of outcomes-based supervision depends on the continuous, systematic and creative application of outcomes-based principles. One of the most important principles of outcomes-based 
supervision as far as the supervisor of social workers/students is concerned, is that the community and appropriate role players in practice and welfare agencies should in one way or another be involved in the supervision process in order that social workers/students may come to understand changing needs, phenomena, policies and structures. Operationalising supervision by means of its functions of education, management and support does not therefore occur in isolation. To implement this principle, however, supervisors need to take the initiative in incorporating the role players concerned in the supervision process in an appropriate manner.

Another fundamental principle of outcomes-based supervision is that it is worker/student centred and that all workers/students can learn and achieve, but not necessarily at the same time or in the same manner. The focus is on the successful achievement of outcomes and not on when or how much time is needed to achieve the outcomes. That is why all workers/students can achieve high standards. Consequently it is necessary to adjust to the tempo of the workers/students by providing them with the support to develop to their full potential.

The supervisor must be flexible during supervision, because the focus is not on procedures, but on the outcomes that the worker/student must attain. This implies that the worker/student must know beforehand what outcomes he/she is expected to achieve. In this regard various opportunities must be made available for workers/students to demonstrate the extent to which they have achieved the desired outcomes. What the worker/student achieves, however, must not be measured against what other workers/students achieve, but only against the outcomes that are supposed to be achieved. Workers/students must therefore continually be informed during supervision of the ways in which the outcomes will be assessed. Assessment and feedback need to be ongoing.

Workers/students are expected to take responsibility for their own achievement of the outcomes. For the self-motivated worker/student who successfully achieves outcomes, there is the freedom and flexibility to go on to more complicated tasks. The fact that every individual can be successful must be emphasised continually.

The emphasis during supervision should not be on memorising factual knowledge and scientific information, but rather on developing those competencies that need to be applied in practice situations. Supervision material and methods must therefore be user friendly. The teaching strategies of supervisors must be adapted to fit the learning styles of workers/students and must make provision for diversity.

Planning the supervision programme begins by formulating the exit outcome and not by attending to the start of the supervision programme. Planning therefore occurs back to front, starting with that which must ultimately must be achieved. There must also be an indication of how that which is learned can be used and how it can be applied to new areas. The focus is always on involving the workers/students as active learners and on their development as critical thinkers. This can only be achieved if the supervisor assumes a facilitating role during supervision and if supervision programmes are applied in a flexible, creative and adaptable manner.

\section{EMPOWERMENT SUPERVISION}

Empowerment can easily become simply a buzzword, which would eventually make it a meaningless term. Rees (1991:4) says that “...the term (has) an aspirin-like quality, as though it is a pill for all seasons" and Rappaport (1984:2) adds critically that "We do not know what empowerment is, but like obscenity, we know when we see it". 


\section{Definition of empowerment supervision}

Various definitions of empowerment in different contexts are to be found in the literature. Torre's (1994:84) definition of empowerment in the context of supervision can be accepted as a summary: "For social work educators, empowering teaching-learning is about how we and our students gain knowledge together, how we teach one another, how we integrate what we know with who we are to create our unique and empowering professional voice; and how we use teaching-learning dialogue to engage and support students toward contracting their own professional mind and voice". On the basis of this definition one can agree with Richan (1994:59) that empowerment supervision is not typical of traditional supervision and that the supervisor must have a certain disposition in order to support workers/students in an empowering manner.

\section{The difference between traditional and empowerment supervision}

The fundamental difference between traditional and empowerment supervision may be found in indigenous, but also in international, literature. Kadushin (1992:12), for example, holds the view that the focus of supervision must shift away from traditional educational methods to those of participative education. Knowles $(1971,1995)$ is well known for his contributions on adult education. Walz and Uematsu (1997:26) promote the idea that the knowledge and experience of students must be exploited during teaching and that only creative teaching will develop creativity in students. Cossom (1991:144) defines the role of the person who teaches as that of someone who is not necessarily in control of the teaching situation and who does not necessarily possess all the knowledge there is about the subject. Graham (1997:34) points out that the author Dewey had as early as 1916 criticised the traditional educational methods for only being "telling". Possibly the most famous leader in the movement away from traditional methods in education is Paulo Freire (1972), whose work Pedagogy of the Oppressed inspired other theoreticians and practitioners in this regard.

It is in this context that Robinson $(1994: 15,157)$ highlights the differences between traditional and empowerment education. The author refers to traditional education as a "banking concept", a term he gets from the work of Paulo Freire (1972): "(The) banking concept of education is Paulo Freire's articulation of traditional teaching as depositing of information in the student's head." The author argues that traditional teaching methods are not reliable for meeting the demands of the environment, and it is necessary to focus on empowerment. With this argument in mind, Table 1 illustrates the differences between traditional and empowerment supervision based on the work of Robinson (1994). 


\section{TABLE 1 \\ THE DIFFERENCE BETWEEN TRADITIONAL AND EMPOWERMENT SUPERVISION}

\begin{tabular}{|c|c|}
\hline TRADITIONAL SUPERVISION & EMPOWERMENT SUPERVISION \\
\hline $\begin{array}{l}\text { The supervisor teaches and the worker/- } \\
\text { student is taught. }\end{array}$ & $\begin{array}{l}\text { Both the supervisor and the worker/student are } \\
\text { involved in the teaching and they learn from each } \\
\text { other. }\end{array}$ \\
\hline $\begin{array}{l}\text { The supervisor is the all-knowing expert } \\
\text { and the worker/student is the layperson. }\end{array}$ & $\begin{array}{l}\text { The supervisor is aware of the fact that he/she is not } \\
\text { the all-knowing expert and appreciates the worker/- } \\
\text { student's knowledge and experience. }\end{array}$ \\
\hline $\begin{array}{l}\text { The supervisor is the only one who does } \\
\text { the thinking. }\end{array}$ & $\begin{array}{l}\text { The supervisor and the worker/student are jointly } \\
\text { involved in critical, reflective and imaginative } \\
\text { thinking. }\end{array}$ \\
\hline $\begin{array}{l}\text { The supervisor talks and the worker/- } \\
\text { student listens. }\end{array}$ & $\begin{array}{l}\text { Both the supervisor and the worker/student talk and } \\
\text { listen. }\end{array}$ \\
\hline $\begin{array}{l}\text { The supervisor disciplines and the } \\
\text { worker/student is disciplined. }\end{array}$ & $\begin{array}{l}\text { The supervisor and the worker/student are in } \\
\text { constant interaction and strive to meet each other's } \\
\text { needs instead of one administering the discipline } \\
\text { and the other being the victim. }\end{array}$ \\
\hline $\begin{array}{l}\text { The supervisor makes the decisions and } \\
\text { the worker/student implements them. }\end{array}$ & $\begin{array}{l}\text { The supervisor and the worker/student make joint } \\
\text { decisions, based on what is meaningful to both. }\end{array}$ \\
\hline $\begin{array}{l}\text { The supervisor models and the worker/- } \\
\text { student copies the model. }\end{array}$ & $\begin{array}{l}\text { The worker/student is actively involved in } \\
\text { meaningful experiences, which the supervisor } \\
\text { facilitates. }\end{array}$ \\
\hline $\begin{array}{l}\text { The supervisor selects the content of the } \\
\text { supervision programme, while the } \\
\text { worker/student remains uninvolved and } \\
\text { simply accepts everything. }\end{array}$ & $\begin{array}{l}\text { The supervisor and the worker/student jointly } \\
\text { participate in choosing the content of the super- } \\
\text { vision programme and changing it as their needs } \\
\text { change. }\end{array}$ \\
\hline $\begin{array}{l}\text { The supervisor uses his/her personal } \\
\text { authority to control the worker/student. }\end{array}$ & $\begin{array}{l}\text { The supervisor uses his/her personality traits to } \\
\text { maintain authority, which is based on mutual } \\
\text { respect. }\end{array}$ \\
\hline $\begin{array}{l}\text { The supervisor personalises the learning } \\
\text { process, while the worker/student is only } \\
\text { an object. }\end{array}$ & $\begin{array}{l}\text { Together the supervisor and the worker/student } \\
\text { personalise the learning process and they share } \\
\text { ownership of the teaching. }\end{array}$ \\
\hline
\end{tabular}

It is clear from Table 1 that empowerment supervision of social workers/students resembles the principles of adult education (Knowles, 1971, 1995). It is preferable in this regard, however, to use the term empowerment supervision instead of adult education. The reason for this is that it is of questionable value to label workers/students as fitting into either the andragogy or pedagogy cadre (Davenport \& Davenport, 1988; Kramer \& Wrenn, 1994).

Table 1 also implies that empowerment supervision is able to accommodate a diversity of learning styles. Unlike in traditional supervision, the supervisor does not dictate to the workers/students by using certain teaching strategies in response to specifically identified learning styles of 
worker/students, for example, as is suggested by Bogo and Vayda (1987), Kolb (1973, 1981, 1984), Raschick, Maypole and Day (1998) and Van Soest and Kruzich (1994). Empowerment supervision is outcomes-based, which in turn is worker/student centred. It therefore comprises teaching strategies that result from the joint planning of supervisors and workers/students so as to provide for a diversity of learning styles.

\section{Principles of empowerment supervision}

Sturgeon (1998: 32- 34) concretises the term empowerment, which can also be made applicable to supervision provided to social workers/students. According to Sturgeon, empowerment models are aimed at creating independence. Applied to supervision, this involves the maximum participation of the worker/student in the supervision process, while at the same time also respecting their selfdetermination. The purpose of empowerment is therefore to lead to capacity building of workers/students, so as to develop their self-control regarding their reactions and decisions.

The above aim can only be achieved if the supervisor lets go of the power associated with the title of "supervisor". The supervisor must therefore assume a facilitation role, so that a relationship of partnership can exist between the supervisor and the worker/student. The shared relationship must be directly aimed at facilitating the worker's/student's taking of responsibility for selfdevelopment (Richan 1994:60-69). It implies that the worker/student accepts co-responsibility for his/her own development and supervision. The traditional vertical worker/student-supervisor interaction must also change to a horizontal dialogue; workers/students must be cognitively and affectively empowered and motivated to accept challenges with confidence; and the worker/student environment must be mobilised as a resource to support the worker/student (Finch, Lurie \& Wrase, 1997:144-140; Richan, 1994; Torre, 1994:88-92).

According to Miley, O’Melia \& DuBois (2001:77-81) empowerment should to take place from a strengths perspective. It implies that all the possibilities or potential of the worker/student must be developed and activated, that the focus must be on the current situation and that a vision for the future must always be created. It is important to guard against focusing on the past and its connection with current behaviour and performance. For this reason one must continue to set challenges for the future. Empowerment of workers/students from a strengths perspective therefore involves the development of workers/students' existing competencies, which means and the focus must not only be on the workers/students' deficiencies, learning needs and problems.

\section{CONCLUSION}

In this article the value of the competence model for the supervision of social workers/students in South Africa is demonstrated by showing that it is situation-relevant in the local environment. It would appear, however, that in order to measure up to Guttman, Eisikovits \& Maluccio's (1988:287) ideal that "...social work education, competence-oriented supervision, and practice become intertwined", a complete transformation from traditional supervision to empowerment and outcomes-based supervision is required. The reality in South Africa at present is that the education system is outcomes-based and that social workers and students must be empowered to meet the demands of professional practice and of the professional environment. Operationalising a competence model will therefore add value to the supervision provided to social workers and students in South Africa, by doing the right thing at the right time and in the right place. 


\section{REFERENCES}

BOGO, M. \& VAYDA, E. 1987. The Practice of Field Instruction in Social Work. Theory and Process - with an Annotated Bibliography. Toronto: University of Toronto Press.

CLAASSEN, J.C. 1998. Learning support material in outcomes-based education. In: PRETORIUS, F. (ed) Outcomes-based education in South-Africa. Johannesburg: Hodder \& Stoughton.

COSSOM, J. 1991. Teaching from Cases: Education for Critical Thinking. Journal of Teaching in Social Work, 5(1): 139-155.

DAVENPORT, J.A. \& DAVENPORT 111, J. 1988. Individualizing Student supervision: The Use of Andragogical-Pedagogical Orientation Questionnaires. Journal of Teaching in Social Work, 2(2): 83-93.

ENGELBRECHT, L.K. 2002. 'n Maatskaplike ontwikkelingsgerigte perspektief op supervisie aan maatskaplikewerkstudente by opleidingsinstansies in Suid-Afrika. Stellenbosch: University of Stellenbosch. (Ph.D thesis)

FINCH, J.B., LURIE, A. \& WRASE, B.J. 1997. Student and Staff Training; Empowerment Principles and Parallels. The Clinical Supervisor, 15(1):129-143.

FREIRE, P. 1972. Pedagogy of the Oppressed. London: Penguin Books.

GRAHAM, M.A. 1997. Empowering Social Work Faculty: Alternative Paradigms for Teaching and Learning. Journal of Teaching in Social Work, 15(1/2):33-45.

GUTTMAN, E., EISIKOVITS, Z. \& MALUCCIO, A.N. 1988. Enriching Social work Supervision From the Competence Perspective. Journal of Social Work Education, 24(3):278-288.

KADUSHIN, A.E. 1992. Supervision in Social Work. ( $3^{\text {rd }}$ ed) New York: Columbia University Press.

KAPLAN, T. 1991. Reducing Student Anxiety in Field Work: Exploratory research and Implications. The Clinical Supervisor, 9(2):105-117.

KNOWLES, M.S. 1971. The Modern Practice of Adult Education - Andragogy Versus Pedagogy. New York: Association Press.

KNOWLES, M.S. 1995. Designs for Adult Learning: Practical Resources, Exercises, and Course Outlines From the Father of Adult Learning. Alexandria: American Society for Training and Development.

KOLB, D.A. 1973. An experiential learning theory. Experience as source of learning and development. New Jersey: Prentice-Hall.

KOLB, D.A. 1981. Student learning styles and disciplinary learning environments. Diverse pathways for growth. In: CHICKERING, A. (ed) The future American college. San Francisco: Jossy Bass.

KOLB, D.A. 1984. Experiential learning: Experience as the source of learning and development. Englewood Cliffs, New Jersey: Prentice-Hall.

KRAMER, B.J. \& WRENN, R. 1994. The Blending of Andragogical and Pedagogical Teaching Methods in Advanced Social Work Practice Courses. Journal of Teaching in Social Work, 10(1/2): 43-63. 
LUCKETT, K. 1997. Programmes Handbook: Guidelines for Programme Design, Specification, Approval and Registration at the University of Natal. Durban: University of Natal.

MILEY, K.K., O’MELIA, M. \& DUBOIS, B. 2001. Generalist social work practice. An empowering approach. $3^{\text {rd }} \mathrm{ed}$. Boston: Allyn and Bacon.

MINISTRY FOR WELFARE AND POPULATION DEVELOPMENT 1997. White Paper for Social Welfare. Notice 1108 of 1997. Government Gazette, 386 (18166). Pretoria, 8 August.

OLIVIER, C. 1998. How to educate and train outcomes-based. Pretoria: Van Schaik Publishers.

PRETORIUS, F. 1998. (ed) Outcomes-based education in South-Africa. Johannesburg: Hodder \& Stoughton.

RAPPAPORT, J. 1984. Studies in empowerment: Introduction to the issue. In: RAPPAPORT, J., SWIFT, C. \& HESS, R. (eds) Studies in empowerment: Steps toward understanding and action. New York: The Haworth Press.

REES, S. 1991. Achieving power: practice and policy in social welfare. North Sydney: Allen and Unwin.

RASCHICK, M., MAYPOLE, D.E. \& DAY, A. 1998. Improving field education through Kolb Learning Theory. Journal of Social Work Education, 34(1): 31-42.

RAMASAR, P. 1988. Preference of Teaching Styles and strategies Related to System Variables, Educational Qualifications and Experiential Backgrounds: A Study Among Social Work Educators in South African Universities. Maatskaplike Werk/ Social Work, 24(3): 176-189.

RICHAN, W.C. 1994. Empowering Social Work Students. In: GUTIÉRREZ, L. \& NURIUS, P. (eds) Education and research for Empowerment Practice. Washington: Centre for Policy and Practice Research.

ROBINSON, H.A. 1994. The Transformation of Empowerment: The Transformative power of classroom Interaction. London: The Falmer Press.

SHARDLOW, S. \& DOEL, M. 1996. Practice learning and teaching. London: Macmillan Press Ltd.

RSA MINISTRY OF EDUCATION 1995. South African Qualifications Authority Act, 1995 (Act 58 of 1995) Government Gazette, Vol. 364, No. 16725 (4 October). Pretoria: Government Printer.

SOUTH AFRICAN QUALIFICATIONS AUTHORITY 1998. Regulations under the South African Qualifications Authority Act, 1995 (Act no. 58 of 1995) Government Gazette, Vol. 393, No. 18787 (28 March 1998). Pretoria: Government Printer.

STURGEON, S. 1998. The future of casework in South Africa. In: GRAY, M. (ed) Developmental Social Work in South Africa. Johannesburg: David Philip Publishers.

TORRE, E.L. 1994. Towards a mind of my own: A constructive developmental model for empowering student learning in social work. In: GUTIÉRREZ, L. \& NURIUS, P. (eds) Education and research for Empowerment Practice. Washington: Centre for Policy and Practice Research.

TSUI, M-S. \& HO, W-S. 1997. In search of a Comprehensive Model of Social Work Supervision. The Clinical Supervisor, 16(2):181-202. 
VAN SOEST, D. \& KRUZICH, J. 1994. The Influence of Learning Styles on Student and Field Instructor Perceptions of Field Placement Success. Journal of Training in Social Work, 9(1/2):49-69.

WALZ, T. \& UEMATSU, H. 1997. Creativity in Social Practice: A pedagogy. Journal of Teaching in Social Work, 15(1/2):17-31. 